\title{
Antonin Artaud: pour en finir avec le jugement de Dieu, e Artaud contra o juízo dos psiquiatras
}

\section{Antonin Artaud: pour en finir avec le jugement de Dieu, or Artaud against the judgment of shrinks}

\author{
GILMAR HENRIQUE DA CONCEIÇÃO'
}

ANA CAROLINA ACOM²

Resumo: Neste artigo apresentaremos Artaud, cujo combate 'para pôr fim ao julgamento de Deus', se traduz também contra o juízo dos psiquiatras, mas não só a ele. Segundo Deleuze, Artaud queria acabar de vez com o universo do "juízo", descobrir um novo continente. Será através de sua "escrita de sangue" e desenvolvimento do sistema da crueldade que Artaud inverte qualquer subjugo moral ou outras amarras que impeçam o pensamento de pensar. Conforme Artaud, o teatro da crueldade reflete as condições da sociedade e as suas mazelas, dentro de um panorama de total controle do corpo, as diferentes formas de repressão social expressas no corpo. Montaigne, um dos pioneiros a entender a crueldade como algo próprio do ser humano, argumenta que temos uma propensão para a crueldade. Assim, Montaigne chama atenção para o fato de que o prazer da crueldade é inerente às pessoas. Em Artaud, o teatro da crueldade, propõe mudanças na atuação, na estruturação das peças, bem como na relação do teatro com o público, buscando perturbar os repousos dos sentidos para trazer a revelação, a afirmação e - mediante golpes profundos - fazer vazar todos os abscessos coletivamente.

Palavras-chave: Artaud. Julgamento. Crueldade. Teatro.

Abstract: In this paper we present Artaud, whose fight 'to end the judgment of God', is also reflected against the judgment of psychiatrists, but not only him. According to Deleuze, Artaud wanted to put an end to the universe of "judgment", discover a new continent. Will be through its

${ }^{1}$ Docente do Curso de Filosofia/UNIOESTE.

${ }^{2}$ Mestre em Educação pela UFRGS, na Linha de Pesquisa "Filosofias da Diferença”. 
Antonin Artaud: pour en finir avec le jugement de Dieu, e Artaud contra o juízo dos psiquiatras

"written in blood" and development of the cruelty that Artaud system reverses any moral subjugation or other tethers that prevent the thought of thinking. As Artaud, the theater of cruelty reflects the conditions of society and its ills, within a panorama full body control, the different forms of social repression expressed in the body. Montaigne, one of the pioneers to understand cruelty as something very human, argues that we have a propensity for cruelty. So Montaigne draws attention to the fact that the pleasure of cruelty is inherent in people. In Artaud the theater of cruelty, proposes changes in performance, structuring parts as well as the theater's relationship with the public, seeking to disrupt the homes of the senses to bring revelation, the affirmation and -through deep strokes - to leak all abscesses collectively.

Keywords: Artaud. Judgment. Cruelty. Theater.

\section{Introdução}

De cara, queremos fazer um alerta: são muitos os riscos que correm os estudiosos que teimam em enquadrar um artista multifacetário e pulsante, um escritor tão complexo, irrepetível e rebelde como é o caso de Artaud. Nós corremos esse risco, brincando com Artaud que, a todo o momento, insistiu em fugir de nossa 'introdução-desenvolvimento-e-conclusão', mas acreditamos que captamos um pouco de seu fel e de seu mel. É o resultado disso que queremos compartilhar, neste trabalho. De fato, Artaud transforma o seu sofrimento em criação. Inclusive, a catástrofe da Segunda Guerra significou, para Artaud, catástrofe íntima visto que ele a passou internado em hospícios, em Ville-Evrard e Rodez, onde recebeu tratamento por eletrochoque. Em Escritos de um Louco (2010) se caracteriza, acertadamente, o nosso autor: rebelde, maldito, marginalizado e incompreendido durante toda a sua vida, tornou-se 
a encarnação máxima do gênio romântico, da imagem do artista iluminado e louco. Antonin Artaud passou a ser reconhecido posteriormente à sua morte como um dos mais marcantes e inovadores criadores do século XX. Ao longo de sua vida, ele se recusou a dobrar-se, desafiando rotulações e diagnósticos, ainda que ao preço de tornar-se um "trapo".

Aquilo que foi julgado por delírio e sintoma de loucura, agora é referência obrigatória para as mais avançadas correntes do pensamento crítico e criação artística nas suas várias manifestações: teatro, arte de vanguarda e criações experimentais, manifestações coletivas e espontâneas, poesia, linguística e semiologia, psicanálise e antipsiquiatria, cultura e contracultura. Artaud escreveu: "O que se entende por autêntico alienado? É um homem que prefere tornar-se louco - no sentido social da palavra - antes do que trair uma ideia superior da honra humana. [...] Porque um alienado é, na realidade, um homem ao qual a sociedade se nega a escutar, e ao qual quer impedir que expresse certas verdades insuportáveis" (ARTAUD, s/d, p. 12).

\section{Os escritos demolidores de Antonin Marie-Joseph Artaud: de louco a gênio}

Bem cedo, Artaud apresentou sérios problemas de saúde, inclusive neurológicos. Sofreu de meningite aos cinco anos. Teve convulsões na adolescência e seu primeiro internamento em sanatório ocorreu aos 19 anos, passando por sucessivos tratamentos e pelas mãos de vários psiquiatras e psicanalistas enquanto viveu. Aos 24 anos, começa a tomar láudano, uma tintura de ópio, para aliviar suas dores de cabeça, tornando-se dependente de heroína e de ópio. Em função disso, permaneceu por muitos anos internado em 
Antonin Artaud: pour en finir avec le jugement de Dieu, e Artaud contra o juízo dos psiquiatras

manicômios, sendo "tratado" com choques elétricos. Não obstante, Artaud conseguiu deixar um legado artístico e cultural de relevo muito expressivo. Não tenhamos dúvidas: ele era um louco profundo, dotado de uma genialidade expressiva e exuberante, capaz de movimentar a incapacidade de pensar dos seus adversários psiquiátricos e contemporâneos.

Em 1920, Artaud foi apresentado à companhias de teatro por seu tio, em Paris, e liga-se a setores avançados e atuantes da vida cultural francesa, apresentado por seu tio que era produtor teatral e pelo Dr. Toulouse, seu psiquiatra e também um intelectual bastante ativo. Consegue bons papéis como ator. Em 1924, passa a dedicar-se também ao cinema, trabalhando com alguns dos principais diretores da época.

Como escritor Artaud produziu uma obra imensa: são 16 volumes pela edição Gallimard, que ainda assim é incompleta, já que até hoje continuam aparecendo inéditos seus. Contribui, para isso, a multiplicidade de sua própria obra: são poemas, cartas, textos de palestras, ensaios, artigos, manifestos, narrativas, traduções e adaptações, peças de teatro, entrevistas e depoimentos, roteiros, sinopses de cinema, etc. Em Artaud, tudo é obra, tudo tem literalidade e apresenta interesse, desde os textos mais acabados, mais próximos de algo com começo, meio e fim (como Heliogábalo), até as cartas, os fragmentos, as versões e até os apontamentos de cartas. Isso porque Artaud não buscava uma transcendência dada pela permanência da obra, pela sua inscrição e codificação nos anais da literatura, mas, sim, pela sua efetividade, pela expressão das suas ideias e consequente transformação em algo que as ultrapassasse e se inscrevesse não na história da literatura, mas no real, na História 
como totalidade.

Artaud participou do movimento surrealista de 1924 até 1926, de maneira ativa e assídua. Em suas reservas ao surrealismo, Artaud ressaltava que o pensamento não se choca contra um núcleo do sonho, mas que os sonhos antes ricocheteiam sobre um núcleo do pensamento que lhes escapa. Os ritos do peiote, segundo Artaud, não são sonhos, mas estados de embriaguez ou sono. Assim, Artaud rompe com os surrealistas na primeira divisão significativa desse movimento, junto com outros autores, quando foi decidida a adesão do surrealismo ao marxismo e ao Partido Comunista. Depois da ruptura com o Surrealismo, Artaud passa a dedicar-se ao Théatre Alfred Jarry, grupo teatral de vanguarda que durou de 1926 até 1929 e que, em meio a grandes dificuldades financeiras, produziu espetáculos polêmicos e inovadores. Depois de uma sucessão de fracassos (incluindo palestras nas quais o público abandonava a sala ou o vaiava) e que culmina com Les Cenci, Artaud resolve dar uma guinada radical: troca o texto pela vida e vivencia, pessoalmente, a realidade mítica que tanto o fascinava e que era tematizada na sua obra. Para tal, consegue uma subvenção que lhe permite ir ao México pesquisar o ritual do peiote entre os índios Taraumaras. A viagem tem várias finalidades: Artaud quer sair do ambiente cultural europeu, em que não o entendiam e que o sufocava. Ele também busca unir cura, através da magia dos índios, para seus problemas de saúde e sua dependência da droga. Acaba encontrando a antevisão do seu calvário, conforme assinala num dos trechos da Viagem ao País dos Taraumaras (Willer, 1983).

Depois de uma infinidade de eventos, na fase final de sua vida, Artaud escreve, torrencialmente, e os livros vão sendo publicados à 
Antonin Artaud: pour en finir avec le jugement de Dieu, e Artaud contra o juízo dos psiquiatras

medida que ele os termina. Entre eles, ressaltamos o texto Pour en Finir Avec le Jugement de Dieu, que em fins de 1947, é gravado para o programa La Voix des Poètes da Radiodifusão Francesa.

Nas palavras de Artaud, no artigo "O Teatro e a Crueldade", do livro O Teatro e Seu Duplo trata-se de reconhecer os danos do teatro psicológico oriundo de Racine que nos desacostumaram dessa ação violenta e imediata que o teatro deve ter (ARTAUD, 2006). A finalidade do teatro da crueldade não é o prazer de assistir ao espetáculo cruel, mas consiste em reencontrar a primeira unidade do mundo que é tão-somente o Nada originário. Em Le Théatre et son double, Artaud (2006) afirma que "a vida é crueldade", mas também, que "não existe crueldade sem consciência".

A crueldade da vida pertence então ao ser consciente, ao homem. Um animal, mesmo carnívoro e violento, não é em nada cruel. E o instinto do tigre não é crueldade. Apenas o homem vive na e pela crueldade. É que o homem não é imediatamente na vida. Existir significa se encontrar fora de si, fora de seu ser mais íntimo e da evidência primeira da vida. A consciência surge dessa dilaceração, desta separação do homem com o fluxo contínuo da vida (DUMOULIÉ, 2010, p. 63).

Artaud resgata o corpo e a imanência. Ora, o que expressa isto com maior propriedade e crueza do que o ato de cagar. Observemos um poema de Artaud que compõe a terceira parte da peça radiofônica Para dar um fim ao juízo de deus, A Busca da Fecalidade:

[...] Deve-se ao fato de o homem

ter um belo dia

detido

a ideia do mundo.

Diaphonía, ISSN 2446-7413, v. 2, n. I, 2016 
Dois caminhos estavam diante dele:

o do infinito de fora

o do ínfimo de dentro.

E ele escolheu o ínfimo de dentro

onde basta espremer

o pâncreas,

a língua,

o ânus,

ou a glande.

E deus, o próprio deus espremeu o movimento.

É deus um ser?

Se o for, é merda.

Se não o for,

não é.

Ora, ele não existe

a não ser como vazio que avança com todas as suas formas

cuja mais perfeita imagem

é o avanço de um incalculável número de piolhos.

"O Sr. Está louco, Sr. Artaud? E então a missa?"

Eu renego o batismo e a missa.

Não existe ato humano

no plano erótico interno

que seja mais pernicioso que a descida

do pretenso Jesus-cristo

nos altares.

Ninguém me acredita

e posso ver o público dando de ombros

mas esse tal cristo é aquele que

diante do percevejo deus

aceitou viver sem corpo

quando uma multidão

descendo da cruz

à qual deus pensou tê-los pregado há muito tempo,

se rebelava

e armada com ferros,

sangue, 
Antonin Artaud: pour en finir avec le jugement de Dieu, e Artaud contra o juízo dos psiquiatras

fogo e ossos

avançava desafiando o Invisível

para acabar com o JULGAMENTO DE DEUS (transmissão radiofônica: "PARA ACABAR COM O JULGAMENTO DE DEUS").

Quando, todavia, nosso corpo se torna um organismo, lhe dão uma utilidade; ele se insere em nossa sociedade para realizar determinados fins. Nosso desejo é esmagado, organizado externamente, nossos órgãos são capturados, amarrados dentro de uma lógica capitalista, ordenados. É assim que nossos órgãos se tornam nossos inimigos. Foi por isso que Artaud declarou guerra aos próprios órgãos. A vida torna-se fraca, o desejo é canalizado, tudo trabalha pela produção, pela finalidade. Não compreendemos o Corpo sem Órgãos; o vivemos. O corpo, afastado daquilo que pode, perde sua capacidade revolucionária e se torna doente, perde sua capacidade de criar o real para aceitar a vida medíocre que lhe dão. Deleuze desenvolve assim o conceito de Corpo sem Órgãos, retirado de Artaud:

Artaud apresenta esse 'corpo sem órgão' que Deus nos roubou para introduzir o corpo organizado sem o qual o juízo não se poderia exercer. $\mathrm{O}$ corpo sem órgãos é um corpo afetivo, intensivo, anarquista, que só comporta polos, zonas, limiares e gradientes. Uma poderosa vitalidade não-orgânica o atravessa. [...] A vitalidade não-orgânica e a relação do corpo com forças ou poderes imperceptíveis que dele se apossam ou dos quais ele se apossa, como a lua se apossa do corpo de uma mulher: Heliogábalo anarquista dará incessantemente na obra de Artaud testemunho desse enfrentamento com as forças e os poderes, como outros tantos devires mineral, vegetal, animal. Criar para si um corpo sem órgãos, encontrar seu corpo sem órgãos é a maneira de escapar ao juízo (DELEUZE, 2013, p. 168-

Diaphonía, ISSN 2446-7413, v. 2, n. I, 2016 
169).

A 4 de março de 1948, Artaud é encontrado morto em seu quarto. Postumamente, a influência e a repercussão da obra e das ideias de Artaud foram se ampliando de forma crescente. Por exemplo, para Foucault, Artaud virou pelo avesso, isto é, subverteu completamente as noções tradicionalmente aceitas sobre a relação entre criação e loucura: não são mais as obras dos loucos e malditos que precisam justificar-se diante da psicologia, mas sim a psicologia que agora deve tentar justificar-se diante de tais obras. Também no Anti-Édipo de Deleuze e Guattari, Artaud é citado para fundamentar a noção de "esquizoanálise", de "máquinas desejantes" e do antagonismo entre a paranoia da nossa sociedade e o esquizoidismo que busca a plena satisfação do desejo.

A Carta ao Papa antecipa o Para Acabar com o Julgamento de Deus em suas críticas contundentes ao cristianismo. Também é significativo que, durante a rebelião de maio de 68 na França, a Carta aos Reitores das Universidades Europeias, de 1925, tenha servido como panfleto revolucionário e sido afixada na Sorbonne - a mesma Sorbonne onde suas conferências eram vaiadas em 1931 e 1933. Nesta carta, Artaud registra:

$\mathrm{Na}$ estreita cisterna que chamais "Pensamento" os raios do espírito apodrecem como montes de palha. [...] O espírito "gelado" range entre as lâminas minerais que o oprimem. E a culpa é de vossos sistemas embolorados, de vossa lógica de dois-e-dois-são-quatro; a culpa é vossa, reitores, apanhados na rede dos silogismos. Fabricais engenheiros, magistrados, médicos a quem escapam os verdadeiros mistérios do corpo, as leis cósmicas do ser; falsos sábios, cegos para o além, filósofos que pretendem reconstruir o Espírito. $\mathrm{O}$ menor ato de criação 
Antonin Artaud: pour en finir avec le jugement de Dieu, e Artaud contra o juízo dos psiquiatras

espontânea constitui um mundo mais complexo e mais revelador que qualquer sistema metafísico (ARTAUD s/d, p. 22).

Artaud amplia a crítica aos reitores, na medida em que seu olhar se volta contra a própria razão ocidental - ciência e filosofia - e constata uma crueldade escondida, na primeira, e uma potência castradora na segunda:

A razão ocidental, ela mesma, exerce uma crueldade escondida por trás de sua aparente frieza: o trabalho do conceito, da dialética, da moral, são sistemas de crueldade. Diariamente tem que cortar, retalhar na matéria viva. Sem falar da crueldade experimental da ciência, da biologia, da medicina. Mas a filosofia, à força de negar sua própria crueldade intelectual, sua incrível potência castradora, torna-se incapaz de pensar a crueldade inerente à vida e ao homem (DUMOULIÉ, 2010, p. 68).

Além da crítica à razão, Montaigne é um dos precursores da temática da crueldade inerente ao ser humano, mesmo antes de Nietzsche e Artaud. O ensaísta, no seu ensaio intitulado Da Crueldade, argumenta que temos uma propensão para a crueldade. Entende, contudo, que a crueldade dos canibais é menos chocante que a dos civilizados: "Os selvagens não me ofendem tanto por assarem e comerem os corpos dos mortos como aqueles que os torturam e perseguem vivos" (MONTAIGNE, 2000, p. 148). Mais adiante, Montaigne chama atenção para o fato de que o prazer da crueldade é inerente ao ser humano:

[...] retalhar e mutilar os membros de outrem; aguçar o espírito inventando tormentos inusitados e mortes novas, sem inimizade, sem lucro, e com a única finalidade de desfrutar do 
agradável espetáculo dos gestos e movimentos lastimáveis, dos gemidos e palavras lamentosas de um homem morrendo em agonia. Pois eis o ponto extremo que a crueldade pode atingir" (MONTAIGNE, 2000, p. 152).

No caso de Artaud, os textos (cartas) do livro teatro da crueldade vão refletir as condições da sociedade e as suas mazelas, dentro de um panorama de total controle do corpo, as diferentes formas de repressão social expressas no corpo. Artaud vai desvelar a possibilidade de romper estes paradigmas da sociedade da exaltação, do consumo, da imagem, simbologias que não dizem nada, que são emblemas culturais nesta sociedade. Além disso, os textos constatam a situação da sociedade e a cultura como um corpo que se produz no aparelismo que serve para reger a Vida. $\mathrm{O}$ teatro não será diferente se não repensar seu conceito. Como um mero reprodutor e repetidor dessa forma de pensamento formatada na sociedade europeia e de organização de civilização, chega ao ponto de se tornar petrificado e se cristalizar na nossa cultura.

Analogamente ao Homem de Artaud, a função do homem na sociedade, como sujeito de auto transformação, pode ser comparado com Buchener em Woyzeck ${ }^{3}$, via as relações desse homem dentro

3 Woyzeck é o nome de uma peça de teatro do autor alemão Georg Büchner. É também o nome do protagonista proletário. Esta peça contém elementos que apareceriam na dramaturgia mundial apenas durante as vanguardas do século XX. Georg Büchner criou um problema insolúvel para o teatro de seu tempo ao introduzir a figura de um pobretão como protagonista de Woyzeck, tragédia inacabada escrita no inverno de 1836/1837. A presença da pobreza num palco que até então fora reduto de personagens de elevada estatura social impunha, já no plano linguístico, sérios entraves à forma dramática. Woyzeck, por força de sua condição social, não pode se expressar na linguagem culta e elevada que, no limite, é partilhada pela burguesia ascendente e pela nobreza decaída. Seu dialeto 
Antonin Artaud: pour en finir avec le jugement de Dieu, e Artaud contra o juízo dos psiquiatras

dessa sociedade de controle, que emprega estratégias psicológicas, hierárquicas e culturais para oprimir e manter os indivíduos sem reação perante o avalanche da sociedade de consumo.

Segundo Artaud, no texto que escreve em homenagem a Van Gogh, ninguém alguma vez escreveu ou pintou, esculpiu, modelou, construiu ou inventou senão para sair do inferno. Conforme ele, não podemos admitir que se impeça o livre desenvolvimento de um delírio, tão legítimo e lógico como qualquer outra série de ideias e atos humanos. Em seu ensaio, Artaud questiona: "E o que é um autêntico louco? É um homem que preferiu ficar louco, no sentido socialmente aceito, em vez de trair uma determinada ideia superior de honra humana. Pois o louco é o homem que a sociedade não quer ouvir e que é impedido de enunciar certas verdades intoleráveis" (ARTAUD, s/d, p. 26). De acordo com ele, a vida é a imitação de algo essencial, com o qual a arte nos põe em contato. Porque não é o homem, mas o mundo que se tornou anormal. Em Artaud, assim como em Van Gogh, pensamento e vida se fundem: "A tragédia já não me basta. Quero transportá-la para minha vida. Eu representei totalmente a minha vida. Onde as pessoas procuram criar obras de arte, eu pretendo mostrar o meu espírito. Não concebo uma obra de arte dissociada da vida" (Artaud, poema: “Quem sou eu?"). Conforme Santos Queiroz (1991, p. 119), "Artaud se dirige obstinadamente à restauração do que foi recalcado pelas relações humanas, pelo

proletário impossibilita o diálogo pleno com as figuras burguesas que integram o círculo de seus exploradores: o médico, o professor e o capitão. A personagem solapa uma das bases da tradição teatral de seu tempo, herdeira da receita neoclássica francesa: o duelo verbal executado por antagonistas de uma mesma posição social, que se submetem a um código comum de comportamentos e a um padrão linguístico refratário a oscilações de estilo (REDONDO, 2006).

Diaphonía, ISSN 2446-7413, v. 2, n. I, 2016 
imperativo categórico, pelo cogito cartesiano, pela moderação dos costumes, pela razão dividida, ou, como diria Nietzsche, pelo enfraquecimento da vontade".

Artaud, por meio de seus escritos, conseguia manter uma ligação com o mundo e revelar o que experimentava. Mesmo hoje, com todos os avanços tecnológicos e com todas as tentativas de se querer situar a loucura no campo das doenças orgânicas e de tentar concebê-la sob o prisma da subjetividade, nenhuma tentativa foi suficiente para quebrar o estigma que acompanha o louco. Estigma este que Artaud viveu, e que o fez ser percebido, muitas vezes como insensato. Marca que uma vez atribuída ao louco nos resguarda de confrontarmos com alguma verdade que ele, o louco, pode revelar a nós. Sua insensatez, sua falta de coerência, talvez desvende uma outra realidade escondida no desatino da humanidade, a qual pode nos incomodar profundamente (SALLES, 2010). Artaud registra que:

Tudo o que age é uma crueldade. É a partir dessa idéia de ação levada ao extremo que o teatro deve se renovar. / Penetrado pela idéia de que a massa pensa primeiro com os sentidos, e que é absurdo, como no teatro psicológico comum, dirigir-se primeiro ao entendimento das pessoas, o Teatro da Crueldade propõe-se a recorrer ao espetáculo de massas; propõe-se a procurar na agitação de massas importantes, mas lançadas umas contra as outras e convulsionadas, um pouco da poesia que se encontra nas festas e nas multidões nos dias, hoje bem raros, em que o povo sai às ruas. / Tudo o que há no amor, no crime, na guerra ou na loucura nos deve ser devolvido pelo teatro, se ele pretende reencontrar sua necessidade. [...] Em suma, acreditamos que há, no que se chama poesia, forças vivas, e que a imagem de um crime apresentada nas condições teatrais adequadas funciona para o espírito como algo infinitamente mais temível do que o próprio crime, realizado 
Antonin Artaud: pour en finir avec le jugement de Dieu, e Artaud contra o juízo dos psiquiatras

(ARTAUD, 2006, p. 96).

A crueldade é humanizante, "na medida em que a crueldade é própria ao homem, e que o ser homem supõe ultrapassar as formas estabelecidas do humano" (DUMOULIÉ, 2010, p. 71). De acordo com Deleuze (2013, p. 17):

O escritor como vidente e ouvidor, finalidade da literatura: é a passagem da vida na linguagem que constitui as Ideias. / Estes são os três aspectos perpetuamente em movimento em Artaud: a omissão das letras na decomposição da linguagem materna (R,T... ); sua retomada numa nova sintaxe ou novos nomes com valor sintático, criadores de uma língua [eTReTe]; enfim, as palavras-sopro, limite assintático para onde tende toda linguagem.

Artaud vê no peiote a possibilidade de cura. Desse modo, o rito do peyote que ele conheceu quando esteve no México entre os índios Taraumaras, afronta as letras e os órgãos, mas para fazê-los passar para o outro lado, nos sopros inarticulados, num indecomponível corpo sem órgãos" (DELEUZE, 2013, p. 28). A medicina e a psiquiatria pensaram a boca somente para comer, mas Artaud a pensa como muitas outras coisas. O que ele arranca à língua materna são palavras-sopros que já não pertencem a língua alguma, e ao organismo, um corpo sem órgãos que já não tem geração. À escritaporcaria, e aos organismos emporcalhados, as letras-órgãos, micróbios e parasitas opõem-se o sopro fluido ou o corpo puro, mas a oposição deve ser uma passagem que nos restitua o corpo assassinado, esses sopros amordaçados (DELEUZE, 2013). Deleuze acrescenta que acontece desse limite final abandonar toda aparência gramatical para surgirem, precisamente nas palavras-sopro de Artaud: a sintaxe desviante de Artaud, na medida em que se propõe 
forjar a língua francesa, encontra a destinação de sua tensão própria nesses sopros ou nessas puras intensidades que marcam um limite da linguagem (DELEUZE, 2013).

Em Van Gogh: o suicidado pela sociedade, Artaud aborda, em certa medida, o tema da loucura e da genialidade. A psiquiatria se destaca como seu alvo maior. Ela, afirma Artaud, serve como um mecanismo útil a uma formação social que reprime e condiciona os indivíduos que se encontram além dos limites estabelecidos. Artaud apresenta as razões da criação da psiquiatria: "Desta maneira, uma sociedade deteriorada inventou a psiquiatria para defender-se das investigações de alguns iluminados superiores cujas faculdades de adivinhação a incomodavam" (ARTAUD, s/d, p. 8). Cita, ainda, o seu caso, em que ouviu do Dr. Gastón Ferdière - médico chefe do manicômio de Rodez - que lhe disse que estava ali para "endireitar" sua poesia. Acrescenta na página seguinte:

[...] Diante da lucidez de Van Gogh em ação, a psiquiatria fica reduzida a um grupo de gorilas realmente obsessivos e perseguidos, que somente dispõe, para mitigar os mais espantosos estados de angústias e opressão humana, de uma ridícula terminologia, digno produto de seus cérebros viciados. $\mathrm{Na}$ verdade, não existe psiquiatra que não seja um notório erotômano" (ARTAUD, s/d, p. 9-10).

Segundo Artaud, foi depois de uma conversa com o doutor Gachet que Van Gogh entrou no seu quarto e suicidou-se. De acordo com Artaud, a razão fede. Na Carta às Escolas de Buda, Artaud salienta, mais uma vez, a sua crítica ao logos, à ordem, e à assepsia (que parecem negar o corpo e a vida): "Sofremos de uma podridão, a podridão da Razão. [...] Nossos escritores, nossos pensadores, nossos doutores, nossos charlatães coincidem nisso: em frustrar a vida" 
Antonin Artaud: pour en finir avec le jugement de Dieu, e Artaud contra o juízo dos psiquiatras

(ARTAUD, s/d, p. 34). O delírio é uma fuga às opressões da vida. Em grande medida, é insuportável o consenso da sociedade, que, na realidade, é "um mundo enjaulado". Para Artaud, nos quadros de Van Gogh que era nada mais do que um pintor, o que há é pintura pura, "não existem fantasmas nos quadros de Van Gogh, nem visões nem alucinações. Somente a tórrida verdade de um sol de meio dia" (ARTAUD, s/d, p. 38).

Artaud amplia a opressão da sociedade sobre todos, não limitaa a Van Gogh ou a si mesmo. Ele afirma que todos somos suicidados pela sociedade, na medida em que ela julga a partir do juízo, que é o juízo de Deus: "Pois não é para este mundo, nunca é para esta Terra onde todos, desde sempre trabalhamos, lutamos, uivando de horror, de fome, de miséria, ódio, escândalo e nojo e onde fomos todos envenenados, embora com tudo isso tenhamos sido enfeitiçados e finalmente nos suicidamos como se não fossemos todos, como o pobre Van Gogh, suicidados pela sociedade!" (ARTAUD, s/d, p. 46). Nosso autor acusa a sociedade pela morte de Van Gogh: "E não se suicidou em um ataque de loucura, pela angústia de não chegar a encontrá-lo; ao contrário, acabava de encontrá-lo, e de descobrir o que era e quem era ele mesmo, quando a consciência geral da sociedade para castigá-lo, por ter rompido as amarras, o suicidou" (ARTAUD, s/d, p. 15).

Artaud, ao considerar o autorretrato pintado por Van Gogh escreve: "O olho de Van Gogh é o de um grande gênio, mas pelo modo como o vejo dissecar-me emergindo da profundidade da tela [...] é o de um filósofo como nunca conheci outro igual em toda a minha vida. Não, Sócrates não possuía aquele olhar, somente o desgraçado Nietzsche teve talvez, antes dele, esse olhar que despe a 
alma, libera o corpo da alma, desnuda o corpo do homem, além dos subterfúgios do espírito" (ARTAUD, s/d, p. 56). Ele conclui que ninguém se suicida sozinho: "Mas no caso de suicídio, precisa-se de um exército de seres maléficos para que o corpo decida-se pelo ato contra natural de privar-se da própria vida" (ARTAUD, s/d, p. 58).

Conforme Artaud, a única superioridade que a psiquiatria possui é a da força. A Carta aos Diretores de Asilos de Loucos é uma síntese perfeita da crítica de Artaud contra o juízo dos psiquiatras, que ele fez em várias oportunidades e escritos. Sigamos, então, a letra de Artaud, examinando o juízo da psiquiatria. Para tanto transcrevemos, quase na integra esta carta.

Artaud começa demolindo o valor da psiquiatria e questiona a própria existência de doenças mentais:

Senhores:

As leis, os costumes, concedem-lhes o direito de medir o espirito. Esta jurisdição soberana e terrível, vocês a exercem segundo seus próprios padrões de entendimento. Não nos façam rir. A credulidade dos povos civilizados, dos especialistas, dos governantes, reveste a psiquiatria de inexplicáveis luzes sobrenaturais. A profissão que vocês exercem está julgada de antemão. Não pensamos em discutir aqui o valor dessa ciência, nem a duvidosa existência das doenças mentais. Porém, para cada cem pretendidas patogenias, onde se desencadeia a confusão da matéria e do espirito, para cada cem classificações, onde as mais vagas são também as únicas utilizáveis, quantas tentativas nobres se contam para conseguir melhor compreensão do mundo irreal onde vivem aqueles que vocês encarceraram? (ARTAUD, 1979, p. 14). 
Antonin Artaud: pour en finir avec le jugement de Dieu, e Artaud contra o juízo dos psiquiatras

Defendendo os internados nos asilos de loucos, Artaud avalia como nefasto o juízo da psiquiatria (amparado pelas leis e pelas ciências) que condena muitas vítimas à prisão perpétua, cuja prática, na realidade, é de brutalidade. Em nome da legitimidade das ações humanas, chega a reivindicar a liberdade do delírio, que julga tão legítimo quanto as ações do logos:

Quantos de vocês, por exemplo, consideram que o sonho do demente precoce ou as imagens que o perseguem são algo mais que uma salada de palavras? Não nos surpreende ver até que ponto vocês estão empenhados em uma tarefa para a qual só existe muito poucos predestinados. Porém não nos rebelamos contra o direito concedido a certos homens - capazes ou não de dar por terminadas suas investigações no campo do espirito com um veredicto de encarceramento perpétuo. [...] E que encerramento! Sabe-se - nunca se saberá o suficiente - que os asilos, longe de ser "asilos", são cárceres horriveis onde os reclusos fornecem mão-de-obra gratuita e cômoda, e onde a brutalidade é norma. E vocês toleram tudo isso. O hospício de alienados, sob o amparo da ciência e da justiça, é comparável aos quartéis, aos cárceres, às penitenciarias. Não nos referimos aqui às internações arbitrárias, para lhes evitar o incômodo de um fácil desmentido. Afirmamos que grande parte de seus internados - completamente loucos segundo a definição oficial - estão também reclusos arbitrariamente. E não podemos admitir que se impeça o livre desenvolvimento de um delírio, tão legítimo e lógico como qualquer outra série de ideias e atos humanos. A repressão das reações antissociais, em princípio, é tão quimérica como inaceitável. Todos os atos individuais são antissociais. Os loucos são as vítimas individuais por excelência da ditadura social. E em nome dessa individualidade, que é patrimônio do homem, reclamamos a liberdade desses forçados das galés da sensibilidade, já que não se está dentro das faculdades da lei condenar à prisão a todos que pensam e trabalham. Sem insistir no caráter verdadeiramente genial das

Diaphonía, ISSN 2446-7413, v. 2, n. I, 2016 
manifestações de certos loucos, na medida de nossa capacidade para avaliá-las, afirmamos a legitimidade absoluta de sua concepção da realidade e de todos os atos que dela derivam (ARTAUD, 1979, p. 14).

Conclui a carta sugerindo que na relação com os internados, nos asilos de loucos, é necessário a seguinte postura: "conversar sem dicionários".

\section{Artaud e as drogas legais e ilegais}

Artaud, usuário de drogas legais e ilegais, escreve contra a proibição do ópio em alguns de textos. Drogas, Sempre as Teremos, indica o nosso autor. Vejamos:

Tenho a intenção declarada de encerrar o assunto de uma vez por todas, para que não venham mais nos encher a paciência com os assim chamados perigos da droga. Meu ponto de vista é nitidamente antissocial. Só há uma razão para atacar o ópio. Aquela do perigo que seu uso acarreta ao conjunto da sociedade. Acontece que este perigo é falso. Nascemos podres de corpo e alma, somos congenitamente inadaptados; suprimam o ópio: não suprimirão a necessidade do crime, os cânceres do corpo e da alma, a inclinação para o desespero, o cretinismo inato, a sífilis hereditária, a fragilidade dos instintos; não impedirão que hajam almas destinadas a seja qual for o veneno, veneno de morfina, veneno de leitura, veneno de isolamento, veneno de onanismo, veneno de coitos repetidos, veneno de arraigada fraqueza da alma, veneno de álcool, veneno de tabaco, veneno da anti-sociabilidade. Há almas incuráveis e perdidas para o restante da sociedade. Suprimam-lhes um dos meios para chegar à loucura, inventarão dez mil outros. Criarão meios mais sutis, mais selvagens; meios absolutamente desesperados. A própria natureza é antissocial na essência - só por usurpação de 
Antonin Artaud: pour en finir avec le jugement de Dieu, e Artaud contra o juízo dos psiquiatras

poderes que o corpo da sociedade consegue reagir contra a tendência natural da humanidade. Deixemos que os perdidos se percam: temos mais o que fazer que tentar recuperação impossível e ademais inútil, odiosa e prejudicial. Enquanto não conseguirmos suprimir qualquer uma das causas do desespero humano, não teremos o direito de tentar a supressão dos meios pelos quais o homem tenta se livrar do desespero. Pois seria preciso, inicialmente, suprimir esse impulso natural e oculto, essa tendência ilusória do homem que o leva a buscar um meio, que lhe dá a ideia de buscar um meio para fugir às suas dores (ARTAUD, 1983, p. 47).

Ainda que Artaud não tenha conhecido o crac', já entendia que a proibição e criminalização de drogas relativamente leves levam à busca por drogas cada vez mais potentes e devastadoras. Observemos como ele foi visionário, pois na medida em que recrudesceu a guerra à marijuana, em seu lugar surgiu o crack. Artaud já alertava: "Suprimam-lhes um dos meios para chegar à loucura; inventarão dez mil outros. Criarão meios mais sutis, mais selvagens; meios absolutamente desesperados" (ARTAUD, 1983, p. 47). Retroativamente, como se pode observar, no âmbito do debate acerca das implicações do uso de drogas consideradas como tóxicas ou alucinógenas, a vivência e a escrita de Artaud impactaram "tanto na fundamentação da crítica à repressão policial e às campanhas anti-drogas, como no estímulo das mais variadas modalidades de aventura psicodélica. Em termos mais gerais, pode-se afirmar que todas as correntes de pensamento genericamente denominados de 'contracultura' devem alguma coisa a Artaud” (WILLER, 1983, p. 8).

Artaud quando escreve, enfrenta as palavras. Usa muitas vezes, para se fazer sentir, o vocabulário mais chulo. Sacode a hipocrisia dos que prefeririam não ouvir. Dejetos, secreções, chamados pelos seus 
nomes populares, misturam-se e dão forte colorido a textos polêmicos. Há nele a necessidade de gritar com a escrita, via de acesso à realidade circundante. Há coerência no pensamento, nas ações e na obra de Artaud como um todo. De crítico de arte a defensor de minorias culturais, seus textos se misturam às suas tristezas e ataques de cólera. Em períodos de melhora de sua saúde, o artista é órgão integrante no corpo da sociedade, e responde à realidade vital que o circunda. Artaud é, por excelência, um contestador. Seu talento, aliado a uma vida menos dura, teria, com certeza, trilhado caminhos menos árduos (MACHADO, 2011).

\section{Dar um fim ao juízo}

Em última instância, o problema na filosofia de Gilles Deleuze sempre acaba remetendo à "gênese do pensamento": quais são as condições de efetividade para engendrar o pensar no próprio pensamento? Aparentemente, "dar um fim ao juízo" indica um caminho para o pensamento. Pensamento este que torna-se condição para a verdadeira criação (DELEUZE, 2006). Deleuze, ao escrever livros com seus intercessores, filósofos, artistas ou escritores, desvenda ou repensa o processo de criação desses pensadores, e o que se passa com os seus pensamentos. Em 1964, em Proust e os Signos, Deleuze apresenta que a filosofia necessita da arte, e que o pensamento é criação.

$\mathrm{O}$ ato de pensar não decorre de uma simples possibilidade natural; é, ao contrário, a única criação verdadeira. A criação é a gênese do ato de pensar no próprio pensamento. Ora, essa gênese implica alguma coisa que violenta o pensamento, que tira de seu natural estupor, de suas possibilidades apenas abstratas (DELEUZE, 1987, p. 96). 
Antonin Artaud: pour en finir avec le jugement de Dieu, e Artaud contra o juízo dos psiquiatras

Quando Deleuze invoca Artaud, e quando conhecemos "vida e obra" de Artaud, podemos ver a criação em sua plenitude, o pensamento materializado em uma arte-vida livre de julgamentos, em um rompimento completo com tribunais da razão ou juízos morais.

Já assinalamos que Deleuze (2013, p. 162) questiona: "E ArtaudVan Gogh, quem terá sofrido mais do juízo sob essa forma penosa em mais alto grau, a terrível perícia psiquiátrica?" O próprio Artaud, contudo, responde com seu texto sobre Van Gogh, e podemos, como Deleuze o fez, os colocá-los juntos: "não, Van Gogh não era louco, mas seus quadros eram misturas incendiárias, bombas atômicas, cujo ângulo de visão comparado com o de todas pinturas que faziam furor na época, teria sido capaz de transtornar gravemente o conformismo larval da burguesia" (ARTAUD, s/d, p. 9). A obra de Artaud, como a do "suicidado" Van Gogh, é incendiária, absurda, ademais de todo tratamento psiquiátrico, eletrochoques e sofrimentos de fome pelos dias em hospícios e camisas de força.

Artaud jamais aceitou a separação entre vida e obra (WILLER, 2013). Quando publica O Teatro e seu Duplo propõe "uma linguagem livre, plena, capaz não só de falar do corpo, mas de expressar o corpo - e outros níveis da realidade dos quais, em nossa civilização, estamos alienados e separados" (WILLER, 2013, p. 1). Ele rompe com tudo que vinha sendo feito em teatro na Europa. Seu sistema da crueldade propunha "fazer do teatro, no sentido próprio da palavra, uma função; algo tão localizado e preciso quanto a circulação do sangue nas artérias, ou o desenvolvimento, aparentemente caótico, das imagens do sonho no cérebro" (ARTAUD, 2006, p. 104). Em sua vida e obra, no palco dos corredores de hospitais e hospícios, no 
ritual do peiote com os Taraumaras e em suas encenações, ele busca "arrebentar o real, desgarrar os sentidos, desmoralizar ao máximo possível as aparências" (ARTAUD apud WILLER, 2013, p. 10). Através de seu Teatro da Crueldade anseia transformar o mundo, um retorno às origens primitivas, sem amarras morais, mas por via dos excrementos, como uma escrita da alma. Esta é a verdadeira atuação em sua cena. É o teatro da não-representação, tocando diretamente ao cerne dos sentidos - o sistema nervoso - completamente liberto de juízos morais, onde se movem atores e espectadores em uma catarse brutal.

Queremos fazer do teatro uma realidade na qual se possa acreditar, e que contenha para o coração e os sentidos esta espécie de picada concreta que comporta toda sensação verdadeira. Assim como nossos sonhos agem sobre nós e a realidade age sobre nossos sonhos, pensamos que podemos identificar as imagens da poesia com um sonho, que será eficaz na medida em que será lançado com a violência necessária. E o público acreditará nos sonhos do teatro sob a condição de que ele os considere de fato como sonhos e não como um decalque da realidade; sob a condição de que eles lhe permitam liberar a liberdade mágica do sonho, que ele só pode reconhecer enquanto marcada pelo terror e pela crueldade. /Daí o apelo à crueldade e ao terror, mas num plano vasto, e cuja amplidão sonda nossa vitalidade integral, nos coloca diante de todas as nossas possibilidades (ARTAUD, 2006, p. 97).

Ele ainda escreve:

O Teatro da Crueldade foi criado para devolver ao teatro a noção de uma vida apaixonada e convulsa; e é neste sentido de rigor violento, de condensação extrema dos elementos cênicos, que se deve entender a crueldade sobre a qual ele pretende se apoiar. / Essa crueldade, que será, quando necessário, 
Antonin Artaud: pour en finir avec le jugement de Dieu, e Artaud contra o juízo dos psiquiatras

sangrenta, mas que não o será sistematicamente, confunde-se portanto com a noção de uma espécie de árida pureza moral que não teme pagar pela vida o preço que deve ser pago (ARTAUD, 2006, p. 143).

De acordo com Deleuze:

Artaud dará ao sistema da crueldade desenvolvimentos sublimes, escrita de sangue e de vida que se opõe à escrita do livro, como a justiça ao juízo, e acarreta uma verdadeira inversão do signo. [...] O sistema da crueldade enuncia as relações finitas do corpo existente com forças que o afetam, ao passo que a doutrina da dívida infinita determina as relações da alma imortal com os juízos. Por toda parte o sistema da crueldade opõe-se à doutrina do juízo (DELEUZE, 2013, p. 165).

\section{O teatro da crueldade}

Um dos projetos de Artaud, para o Teatro da Crueldade, era encenar A Conquista do México; no entanto, em vez disso, ele foi vivê-la, passando um tempo no país latino, na tribo dos Taraumaras. Assim, sentiu na carne essa "cultura subterrânea", primitiva, em todo o seu potencial subversivo e de desestruturação do juízo em ritual. " $A$ Dança do Peiote é, sem dúvida, a melhor encenação de 'Teatro da Crueldade' de que Artaud chegou a participar, o acontecimento mais próximo da sua noção de como devia ser um espetáculo teatral" (WILLER, 1983, p. 11). Seus escritos sobre essa temporada e experiência, parecem criar um elo e materialização de suas ideias desde o teatro da crueldade, além de "legitimarem" de vez o abandono ao juízo e a qualquer código de conduta moral a fim de que haja criação-pensamento.

A possessão física continuava aí. Este cataclisma que era meu

Diaphonía, ISSN 2446-7413, v. 2, n. I, 2016 
corpo... Após vinte e oito dias de espera, ainda não tinha voltado a mim - ou melhor dizendo, saído até mim. Até mim, esta montagem deslocada, este pedaço de geologia avariada. [...] Pois a cabeça, transbordando de ondas, sem conseguir dominar seus vagalhões, a cabeça sente todos os vagalhões da terra debaixo dela, enlouquecendo-a e impedindo-a de permanecer ereta. Vinte e oito dias dessa possessão pesada, desse montão de órgãos desarrumados que era eu, aos quais tinha a impressão de assistir como se fosse uma imensa paisagem de gelo a ponto de deslocar-se (ARTAUD, 1983, p. 15).

Como mencionamos anteriormente, Artaud descreve a Dança do Peiote, por meio da qual ele encontrou a sua cura:

O dançarino entra e sai e, no entanto, não deixa o círculo. Ele avança deliberadamente para o mal, mergulha nele com uma espécie de horrenda coragem, num ritmo que parece representar a Doença, mais que a dança. E tem-se a impressão de vê-lo subitamente emergir e desaparecer, num movimento que evoca não sei que obscuras tantalizações. Ele entra e sai: "Sair para o dia, no primeiro capítulo", como diz do Duplo do Homem o Livro dos Mortos Egípcios. Pois esse avanço na doença é uma viagem, uma descida PARA SAIR DE NOVO NO DIA. - Ele dá voltas no sentido da Suástica, sempre da direita para a esquerda e pelo alto. Ele pula com seu exército de campainhas, como uma aglomeração de abelhas enlouquecidas e aglutinadas numa crepitante e tempestuosa desordem. Dez cruzes no círculo e dez espelhos. Uma viga com três feiticeiros nela. Quatro coadjuvantes (dois homens e duas mulheres). O dançarino epiléptico e eu, para quem estava sendo feito o rito (ARTAUD, 1983, p. 18).

Na introdução ao texto de Artaud, de Os Taraumaras, Willer (1983) questiona: “Loucura ou dramatização das suas ideias?", em seguida afirma que esta é uma questão que não pode ser colocada, o 
Antonin Artaud: pour en finir avec le jugement de Dieu, e Artaud contra o juízo dos psiquiatras

que seria falsa sob a ótica artausiana. "Pouco importa se o delírio místico de Artaud era a manifestação de um quadro clínico ou uma escolha consciente. Para o próprio Artaud, a diferença entre sintoma e ato consciente é inaceitável, já que ele queria, justamente, abolir e transpor a barreira entre a razão e o inconsciente" (ARTAUD, 1983, p. 12).

É nos estados de embriaguez, bebidas, drogas, êxtases que se buscará o antídoto ao mesmo tempo do sonho e do juízo. Cada vez que nos desviamos do juízo em direção à justiça, entramos num sono sem sonho. [...] Os ritos do peiote, segundo Artaud, os cantos da floresta mexicana, segundo Lawrence, não são sonhos, porém estados de embriaguez ou sono. Esse sono sem sonhos não é daqueles em que dormimos, mas ele percorre a noite e a habita com uma claridade assustadora que não é o dia, mas o Relâmpago (DELEUZE, 2013, p. 167).

\section{O sonho e o mundo do juízo}

Deleuze (2013) expõe o sonho como tribunal, onde os próprios sonhadores são constantemente condenados e se punem, tentando rechaçar seus conteúdos. Esta teoria parece se aproximar da fascinação de Artaud pelo incesto, pois, para que haja uma liberdade absoluta na criação, requer uma linguagem sem exterioridade (WILLER, 2013). "Tocar os tabus da gramática - talvez também da aritmética - é tocar o mandamento surdo a uma sexualidade identificatória: a revolução da linguagem é uma travessia da sexualidade e de todas as coagulações sociais (famílias, seitas, etc.) aderidas a ela" (KRISTEVA apud WILLER, 2013, p. 12). O propósito de Artaud seria um pensamento puro sem filtros morais ou contenções sociais. Dessa forma, a linguagem de seu sistema de crueldade inclui gestos livres, ruídos, "escatologias”, posturas, profanações, e etc. 
"O mundo do juízo se instala como num sonho" (DELEUZE, 2013, p. 167), pois o sonho não é pensamento, não é novo e nem criação, está submetido ao "conhecimento e experiência". Apolo é o deus da Razão, isto é, ao mesmo tempo é deus do juízo, do sonho, e lucidez. O pensamento escapa ao sonho; já a alucinação toca a criação quando o sono sem sonho é intenso.

Deleuze (2003) vê, em Artaud, um artista da profundidade, onde tudo advém de um "Eu" rachado, estilhaçado, desconstruído, preenchido por sopros, linhas de irrupção e devires loucos, um destroçador das palavras. "Artaud, mergulhando na profundidade caótica do corpo, mergulhava também na própria destruição da linguagem, como se essa mesma destruição fosse necessária para o nascimento de uma nova forma de expressão. O que poderá surgir a partir do próprio estilhaçamento do corpo e da palavra?" (CHIH, 2011, p. 258).

De acordo com Heuser (2015, p. 51), Deleuze encontrou "na experiência de escrita/pensamento" de Artaud seu importante intercessor na busca de um pensamento sem imagem, encontrando nele o abandono de vez da representação. Pois seus escritos e pensamentos funcionam como a maior crítica ao modo de pensar, escrever e criar do Ocidente. Artaud destrói as formas, aparentemente, inabaláveis da razão. Parece ter sido ele "quem expressou de modo mais intenso, aquilo que Deleuze também considera ser o começo do pensar" (HEUSER, 2015, p. 51), a criação, único modo de engendrar o pensar no pensamento (DELEUZE, 2006).

Deleuze em, Diferença e Repetição, afirma: 
Artaud diz que o problema (para ele) não é orientar seu pensamento, nem aprimorar a expressão do que ele pensa, nem adquirir aplicação e método ou aperfeiçoar seus poemas, mas simplesmente chegar a pensar alguma coisa. Aí está para ele a única "obra" concebível; ela supõe um impulso, uma compulsão de pensar, que passa por todo tipo de bifurcação, que parte dos nervos e se comunica à alma, para chegar ao pensamento. Assim, o que o pensamento é forçado a pensar é igualmente a sua derrocada central, sua rachadura, seu próprio "impoder" natural, que se confunde com a maior potência, isto é, com os cogitanda, estas forças informuladas, como com outros tantos voos ou arrombamentos do pensamento. Artaud persegue em tudo isto a terrível revelação de um pensamento sem imagem e a conquista de um novo direito que não se deixa representar. Ele sabe que a dificuldade como tal e seu cortejo de problemas e de questões não são um estado de fato, mas uma estrutura de direito do pensamento. Sabe que há um acéfalo no pensamento, assim como um amnésico na memória, um afásico na linguagem, um agnóstico na sensibilidade. Sabe que pensar não é inato, mas deve ser engendrado no pensamento. Sabe que o problema não é dirigir, nem aplicar metodicamente um pensamento preexistente por natureza e de direito, mas fazer com que nasça aquilo que ainda não existe (não há outra obra, todo o resto é arbitrário e enfeite). Pensar é criar, não há outra criação, mas criar é, antes de tudo, engendrar, "pensar" no pensamento. Eis por que Artaud opõe, no pensamento, a genitalidade ao inatismo, mas, igualmente, à reminiscência, estabelecendo, assim, o princípio de um empirismo transcendental; "Sou um genital inato... Há imbecis que se creem seres, seres por inatismo. Quanto a mim, sou aquele que, para ser, deve açoitar seu inatismo. Aquele que, por inatismo, é aquele que deve ser um ser, isto é, sempre açoitar esta espécie de negativo canil, oh!, cadelas de impossibilidade... Sob a gramática, há o pensamento que é um opróbrio mais forte a ser vencido, uma virgem muito mais áspera a se ultrapassar quando é ela tomada como um fato inato. Pois o 
pensamento é uma matrona que nem sempre existiu" (DELEUZE, 2006, p. 213).

Artaud, quando abala os sistemas de crenças, hábitos e emerge um teatro da crueldade, sua poesia ensandecida e carnal, cria algo de fato, pensa o impensável, o não passível de representação. Ele destitui qualquer sistema de juízo. "Desenraizamento que não se dá sem um sofrimento avassalador, pois sofrer e pensar estão secretamente ligados" (HEUSER, 2015, p. 13). Para que haja esse engendramento abrupto do pensamento, as faculdades transpõem seus limites por uma violência sem precedentes, entrando em discordância e gerando dor, dilaceramento (HEUSER, 2015, p. 53). Deleuze (1975) em, Lógica do Sentido, reforça a ideia da criação, ou seja, do próprio pensar, como uma violência. Assim, ele invoca Artaud e outros escritores e traça linhas entre seus pensamentos, martírios e vícios. "Artaud é o único a ter sido profundidade absoluta na literatura e a ter descoberto um corpo vital e a linguagem prodigiosa deste corpo, à custa de sofrimento, como ele diz" (DELEUZE, 1975, p. 96).

Mas, quando Bousquet fala da verdade eterna do ferimento, é em nome de um ferimento pessoal abominável que ele carrega em seu corpo. Quando Fitzgerald ou Lowry falam desta fissura metafísica incorporal, quando nesta encontram, ao mesmo tempo, o lugar e o obstáculo de seu pensamento, a fonte e o estancamento de seu pensamento, o sentido e o não-sentido, é com todos os litros de álcool que eles beberam, que efetuaram a fissura no corpo. Quando Artaud fala da erosão do pensamento como de alguma coisa de essencial e de acidental ao mesmo tempo, radical impotência e, entretanto, autopoder, já o faz partindo do fundo da esquizofrenia. Cada qual arriscava alguma coisa, foi o mais longe neste risco e tira dai um direito imprescritível. Que resta ao pensador abstrato 
Antonin Artaud: pour en finir avec le jugement de Dieu, e Artaud contra o juízo dos psiquiatras

quando dá conselhos de sabedoria e de distinção? Então, falar sempre do fermento de Bousquet, do alcoolismo de Fitzgerald e de Lowry, da loucura de Nietzsche e de Artaud, ficando à margem? Transformar-se no profissional destas conversações? Desejar apenas que aqueles que foram atingidos não se afundem demais? Fazer subscrições e números especiais? Ou então irmos nós mesmos provar um pouco, sermos um pouco alcoolátras, um pouco loucos, um pouco suicidas, um pouco guerrilheiros, apenas o bastante para aumentar a fissura, mas não para aprofundá-la irremediavelmente? (DELEUZE, 1975, p. 160).

Em razão disso, acabar com o juízo de Deus implica em retornar a vida à imanência e, portanto, torná-la mais intensa e digna de ser vivida. Na medida em que libertamos a consciência/corpo de nossa existência - nossa e dos outros -, nos abrimos para o instante, para o frágil e para o diferente.

Em fins de 1947, o texto Para Acabar com o Juízo de Deus é apresentado em peça radiofônica e gravado para o programa La Voix des Poètes da Radiodifusão Francesa: leitura a quatro vozes entremeada de gritos, uivos, efeitos sonoros com tambores, gongos e xilofone. Esta peça radiofônica é apresentada em cinco "atos" --1) Para acabar com o julgamento de deus; 2) Tutuguri: o rito do Sol Negro; 3) A busca da Fecalidade; 4) A questão que se coloca; 5) Conclusão. Em suma, é por meio da "cura pela crueldade" que Artaud busca aplicar ao teatro, objetivando arrancar os condicionamentos da vida em sociedade, a partir de uma entrada em regiões abissais, no desconhecido, e com isso produzir uma libertação de energias reprimidas capazes de provocar uma espécie de restauração no próprio ser humano de tudo aquilo que foi perdido ou que lhe foi tomado. 
O próprio Artaud participou da gravação, dizendo parte dos textos - junto com Roger Blin, Marie Casarès e Paule Thévenin - e cuidando dos efeitos sonoros, com enorme dificuldade, pois mal se sustentava em pé (ele teve que ditar deitado seus últimos textos). Segundo todas as testemunhas e o depoimento daqueles que ouviram a gravação, sua performance foi qualquer coisa arrepiante. Na véspera da data marcada para a transmissão - 2 de fevereiro de 1948 - Wladimir Porché, diretor da Radiodifusão Francesa, a proibiu. Foram feitas duas transmissões em circuito fechado, para intelectuais convidados que pediram sua liberação. A transmissão proibida pelo diretor da rádio, provocou uma grande polêmica que repercute na imprensa. Essa foi a última manifestação de Artaud em vida: como todas as anteriores, marcada pelo escândalo, pela incompreensão e pela derrota.

\section{Considerações finais}

Como salientamos, ao longo deste texto, Artaud explode os pontos fixos, e isso confunde os conservadores de todas as épocas. Entretanto, ele tem consciência disso, ao afirmar na peça radiofônica, já mencionada: "Eu não estou a delirar. Eu não estou louco". Na verdade, nosso autor parece deformar a realidade para transformá-la. Desse modo, quando a palavra não consegue dizer mais nada, Artaud busca dizer o indizível. Para concluir este texto sobre Artaud: seus gritos de dor, de fúria, de obscenidade e de escracho ainda repercutem nos ouvidos de uma sociedade que o massacrou (e ainda massacra?), mas, esta mesma sociedade teve suas entranhas feridas de morte e expostas, publicamente, pelas estocadas dos escritos de um louco paradoxalmente tão lúcido. Afinal, peidos e arrotos explicam o que não tem explicação (MACHADO, 2011). 
Antonin Artaud: pour en finir avec le jugement de Dieu, e Artaud contra o juízo dos psiquiatras

\section{Referências bibliográficas}

ARTAUD, A. Carta aos poderes. Porto Alegre: Editorial Villa Martha, 1979.

. Os Taraumaras. In: WILLER, Cláudio (Org.). Escritos de Antonin Artaud. Porto Alegre: L\&PM, 1983.

. O teatro e seu duplo. São Paulo: Martins Fontes, 2006.

. Van Gogh: o suicidado pela sociedade. 2 ed. Rio de Janeiro:

Achiamé, sd.

CHIH, C. Y. Por uma Estética da Diferença: Um Diálogo entre Deleuze e Artaud. In: Kínesis, Vol. III, nº 05, Julho/2011.

DELEUZE, G. Lógica do sentido. São Paulo: Perspectiva, 1975.

. Proust e os Signos. Rio de Janeiro: Forense Universitária, 1987.

. Diferença e repetição. 2. ed. São Paulo: Graal, 2006.

. Lógica das Sensações. Rio de Janeiro: Jorge Zahar, 2007.

. Crítica e Clínica. São Paulo: Editora 34, 2013.

DUMOULIÉ, C. Antonin Artaud e o teatro da crueldade. Revista Lettres Françaises, 2010, $\mathrm{n}^{\circ} 11$.

HEUSER, E. M. D. Do poderoso Eu ao 'impoder' essencial do pensamento: Gilles Deleuze, um começo para pensar. Texto apresentado no: $7^{\circ}$ Encontro de Estudos e Pesquisas do Laboratório de Artes Visuais (LAV), Universidade Federal de Santa Maria, p. 4061, 2015.

QUEIROZ, A. L. S. "O teatro artaudiano ou a metafísica da carne". Revista O que nos faz pensar, PUCRJ, v. 5, p. 114-129, 1991.

MACHADO, R. M. Genialidade e Loucura - Artaud. In: http://www.webartigos.com/artigos/genialidade-e-loucuraartaud $/ 58519 /$

Diaphonía, ISSN 2446-7413, v. 2, n. I, 2016 
MONTAIGNE, M. Da crueldade. In: Ensaios, II, 11. São Paulo: Martins Fontes, 2000.

REDONDO, T. Tempo e trabalho em Woyzeck, de Georg Büchner. In: Revista Literatura e Sociedade, 2006.

SALLES, N. "Antonin Artaud: o corpo sem órgão". In: Revista $O$ percevejo, 2010.

Coletivo SABOTAGEM. Escritos de um louco Antonin Artaud. http://www.sabotagem.cjb.net WILLER, C. (Org.). Escritos de Antonin Artaud. Porto Alegre: L\&PM, 1983.

WILLER, C. Sobre Antonin Artaud: um ensaio inédito. 2013. (Acesso: https://www.academia.edu/4691151/Sobre_Antonin_Artaud_um_ens aio_inédito

Submissão: 05.04.2016 / Aceite: 13.05.2016 